\title{
THE IMPACT OF ALTERNATIVE POVERTY DEFINITIONS ON THE INTERSTATE ALLOCATION OF FEDERAL FUNDS ${ }^{\dagger}$
}

\author{
Stanley P. Stephenson, Jr.*
}

For more than a decade the federal government has used poverty counts in allocating federal funds to States for ultimate use by the poor. Several different poverty concepts are currently used in determining the amount of federal funds received by each state. A main point to the analysis here is that adverse distributional effects exist in several federal antipoverty fund disbursement schemes: States with high family income averages receive relatively more cash transfers than low income States. It is demonstrated here that an alternative allocation scheme would be an improvement in channeling transfers to poorer States. The use of reciprocals of State income averages, the scheme proposed here, would improve the allocation to poorer areas in a manner similar to the use of the inverse of per capita income in the general revenue sharing formula.

We do not directly consider here the allocative implications of altering the definition of income. For example, recent analysis at the Congressional Budget Office demonstrated that dramatic changes in poverty incidence by region result after including in-kind transfers in post-tax income which is adjusted for underreporting. ' Such an issue is relevant, but beyond our purposes. Instead, we use the Census income definition of pretax, post-transfer income. Implicit income adjustments by region may occur if average State income levels reflect differential living costs; but, the main focus here is on alternative poverty definitions.

In the sections that follow, we first present conceptual and administrative reviews of the major alternative approaches to defining and measuring poverty and note possible ways to make the measures sensitive to geographic differences. We next consider alternative administrative uses of poverty definitions which are currently in use and finally present empirical evidence regarding the allocative implications of different approaches to defining poverty.

\footnotetext{
*Associate Professor of Economics, The Pennsylvania State University.

†This paper is derived in part from a larger study "Relative Measure of Poverty," which is included as a Technical Appendix to The Measure of Poverty, U.S. Department of Health, Education, and Welfare, 1976. I am very grateful to Professors Monroe Newman, John Riew, and Nancy Wentzler of The Pennsylvania State University, and to two anonymous referees for their helpful comments on an earlier version of this paper. These individuals and institutions are not responsible for any errors or opinions contained herein.
} 


\section{DEFINING POVERTY}

If we are to use definitions of poverty as the basis of federal allocations to the States, we must first examine carefully the foundations of those definitions. Poverty, defined in economic terms, encompasses two central questions-how the poverty standard is established and how it varies over time. It may be defined in a relative or an absolute sense. These definitions reflect, respectively, concern for relative deprivation or concern for providing minimal consumption needs. In either case, the level of the poverty line is essentially arbitrary. It is dependent on social attitudes of what is a minimally acceptable level of deprivation. In the following discussion we consider several ways to measure poverty and how to make regional adjustments in the measures.

\section{Absolute Poverty}

At one extreme, absolute poverty is a standard defined by choosing a certain constant dollar value of a reporting unit's income below which a person is deemed poor. Such a measure is invariant over time, or at least invariant over the period until a new standard is set. While convenient and easy to reproduce, these thresholds are conceptually crude. Adjustments for family size and other needs criteria are usually ignored, though they need not be.

The methodology for a second absolute poverty standard, the current "official" poverty definition, was developed by Mollie Orshansky in the mid-1960's." This measure is set by attempting to determine the cost of a physiologically-determined minimum bundle of goods and services. The main problems are the choice of items to include in the bundle and how to keep the cost of the bundle current. This definition might be called a "relatively absolute" standard, because it is absolute in the short run in real terms and relative in the long run as food plans and other components change. ${ }^{3}$

There are several problems with the current administrative use of the subsistence, or near-subsistence, food-based poverty definition. From time to time, there arises, for example, variation among experts regarding exactly how to measure nutritional adequacy; there are an infinite number of dietary combinations and costs that yield a specified number of calories. Secondly, another area of disagreement is exactly how to make equivalency adjustments to reflect sex, age, regional price-of-food differentials, individual activity level, and so forth. ${ }^{4}$

Two additional problems exist with the current official poverty index. First, as Lester C. Thurow has suggested, the programmatic necessity of drawing a poverty line at some specific dollar amount seems to give these estimates an objectivity and specious accuracy that is illusory. ${ }^{5} \mathrm{~A}$ second criticism concerns the means for updating the official poverty lines. Although we discussed the measure as though food plan components were regularly updated, the fact is that the official poverty lines have been kept current mainly by making annual adjustments for national price changes. This problem becomes clear with the following poverty definition: Poverty is the inability of a spending unit to 
command sufficient income-generating resources to be able to consume what society considers a minimum adequate bundle of goods and services. ${ }^{6}$ Note the reference to social opinion. It is not likely that social opinion regarding the poverty line increases annually only as rapidly as prices rise as measured by the CPI. As the average income of society grows, as families become more affluent, "needs" perceived by society will also grow. Moreover, these "needs" changes may vary from region to region. The claim that public opinion about poverty lines rises over time has been made several times, notably many years ago by economists, Schultz ${ }^{7}$ and Johnson. ${ }^{8}$ From these observations, one might conclude that poverty is not best understood as an absolute standard. Instead, poverty is a socially-relative concept such that "standards of poverty vary from nation to nation, from region to region, and from time to time." 9

\section{Relative Poverty Standards}

To many observers, poverty is a relative phenomenon that is best understood not by isolating a subgroup of the population, but rather, by viewing the subgroup in relation to society as a whole. Martin Rein distinguishes several concepts of poverty including: subsistence; achieving and maintaining minimum consumptive levels; and inequality, referring to relative income or relative consumption aspects of poverty. ${ }^{10}$

Perhaps the most purely relative poverty standard is that which is derived from a Lorenz curve. In this case, the income cut-off level, which includes, say, the lowest 10 or 25 percent of the income distribution, is considered a poverty line. Choice of the exact percentum is arbitrary; yet this definition is unambiguous and can easily be reproduced.

A second relative poverty measure is to define as poor any family whose income is less than a fraction of median family income. ${ }^{11}$ The exact value of the fraction is arbitrary, but $50 \%$ of median family income was proposed by Fuchs and is a convenient figure for expository purposes. ${ }^{12}$

The Fuchs variant does not eliminate the need for subjective decision-making regarding the level of the poverty lines. In fact, open and clear judgments about the exact percent of median income are viewed as a point in its favor by proponents. However, how to adjust income by geographic location remains a problem.

\section{POTENTIAL GEOGRAPHIC ADJUSTMENTS IN POVERTY MEASUREMENT}

The federal government has resisted attempts to make geographic poverty adjustments. Aside from the urban/rural differential, one standard is applied to the entire nation. Yet, if needs and average retail prices vary by geographic region (and tastes do not vary systematically), it is inappropriate to use a single needs standard for all regions. Questions of equity arise. This suggests that poverty thresholds should be drawn to reflect region-specific needs. The main 
question is how to develop these regional adjustments in equivalency scales. We consider four alternative procedures. ${ }^{13}$

A first method of adding regional adjustments to the official poverty lines involves the use of region-specific price indexes to update the poverty lines. Since 1969 the method of updating the poverty lines has been to inflate the poverty lines annually by the Bureau of Labor Statistics' Consumer Price Index. A recent study by Akin and Stephenson ${ }^{14}$ used the same techniques and the same data used by BLS to develop the Consumer Price Index with the exception that price indexes were made specific to income class and geographic region. The resultant set of price indexes, especially those for geographic variation, could be used to update poverty lines regionally. The faults with this technique, e.g., the failure to include all persons' market baskets, the failure to allow for substitutions in consumption reflecting changing relative price, etc., are nearly identical to the faults of the present use of the CPI. Initially, the same equivalency matrix of poverty cut-offs could be used. Over time, separate regional price indexes could be used to adjust the original poverty lines to reflect region-specific, cost-of-living changes and, thus, lead to more correct indications of real income disparities than the present alternative.

A second method of adding region-specific price information to poverty lines also involves changes in the poverty lines over time. In the period 1965 to 1969 , the official poverty line was increased annually to reflect increases in the price of food. Since then, overall CPI price changes have been used to adjust the poverty line upward. This procedure is appropriate only if food prices move upward at the same rate as other prices. However, between 1972 and 1973, for example, food cost increases were 14.5 percent versus the total CPI changes of 6.2. Because poor families spend more on food than nonpoor families, such disparities between food prices and the CPI make it necessary to consider the income distribution consequences of the current updating procedure. Returning to an overall food price increase method, or some variant such as updating the food component of the poverty standard by food price increases and the other components by the CPI less food prices, is one procedure. A second procedure, one more in keeping with making the current standard more sensitive to geographic food price differences, is to use as an annual, region-specific benchmark, the average retail food price information. Such price data are currently collected by BLS for most of the same locations used to compute the CPI. Like the regional price index alternative, updating poverty standards by observing regional food price changes may involve only a marginal adjustment in the present updating procedure. (BLS emphasizes that their prices are intended for time-to-time rather than place-to-place comparisons. However, the explanation contained in the BLS "Estimated Food Prices by Cities," suggests that the annual benchmark prices, average retail prices of food by city, might be marginally adjusted in a way to use for updating poverty standards.) Most criticisms of these alternatives are, therefore, also criticisms of the present (or any) updating method. 
A third method for rendering the poverty lines more sensitive to regional cost-of-living differentials is that offered by Watts in his "isoprop" paper. ${ }^{15}$ Lacking price data, Watts was still able to obtain substitutions between items in a necessities bundle by allowing local variation in tastes, needs, and relative prices to be reflected in the sum of expenditures on food, clothing, and shelter when the sums were computed separately for major geographic regions. Watts' approach involved alternative Engel curve estimates with regional dummy variables when the dependent variable was measured by different bundles of purchased necessities. Regional equivalency indexes were thus derived from estimated regression coefficients. (Bellante and Killion have also developed a regression technique which could be extended to poverty line geographic adjustments. ${ }^{16}$ )

In a sense, the first two poverty line adjustments outlined above are similar. Each is a way to update poverty lines. Also, all three methods are normative schemes. In contrast, another approach is currently used to disburse federal funds: the federal government uses several poverty definitions, including relative poverty concepts based on subnational units like a State income level, to distribute funds to States. It is not clear, however, whether within each State, average income level and poverty level, or the average income level and average price level, are positively and highly correlated. ${ }^{17}$ Even if this is found to exist, the use of a State income average is probably a crude proxy for a "needs" criterion in diverse federal programs which subsidize housing, education, and social services. The point is that even if one believes poverty should be counted by a relative poverty method, it does not follow that a relative poverty method is the best way to disburse funds for federal programs which have widely-differing goals and purposes. Later in this paper, we document the disbursement problems which can arise with allocation formulae which depend on State population levels, State income levels, and similar measures. Before doing so, we consider several specific examples of the way poverty definitions enter federal fund disbursement criteria.

\section{EXAMPLES OF FEDERAL PROGRAMS USING ALTERNATIVE POVERTY DEFINITIONS}

Since the development of the official poverty thresholds, several federal statutes have incorporated the official or other poverty definitions into criteria for eligibility or disbursement of federal funds. For example, Title I of the Elementary and Secondary Education Act (ESEA), in part, determines eligibility for federal funds to aid educationally disadvantaged school children based on the official poverty definition.

Another example is the current version of the Comprehensive Employment and Training Act of 1973 (CETA), an umbrella Act which incorporates several poverty definitions. First, eligibility for participation in various manpower programs is made according to whether a person is "economically disadvantaged" or not. A person is "economically disadvantaged" if he (or she) 
is a member of a family receiving cash welfare payments or if family annual income does not exceed the current official poverty standard. ${ }^{18} \mathrm{~A}$ second poverty definition used under CETA to distribute federal funds is a "low-income" audit count. Part of the fund allocative formula reads as follows: "Twelve and one-half percent of the funds subject to the allocation formula shall be allocated on the basis of a prime sponsor's proportion of the number of adults in low-income families within the state. . ."19 A family is considered "low-income" if its income is below $\$ 7,000$ in 1969 dollars. In short, some federal funds under CETA are distributed based on a strictly absolute poverty standard, whereas eligibility for those funds within an area is set according to the official poverty standard, a relatively absolute measure. ESEA and CETA are two examples of federal programs using the current "official" poverty count; we can also point to federal programs using median income poverty standards.

The Housing and Community Development Act of 1979 has, as a main purpose, direct housing aid for the low-income population. Under this Act the current official poverty criteria may be used to determine the "extent of poverty," except for adjustments as appropriate, and, at the sole discretion of the Secretary, for regional or local variations in the income and cost of living. The "extent of poverty" is a key factor in allocating funds to different areas under Title I of the Act. Criteria for assistance eligibility listed in Title II, use two more poverty definitions. First, the term "very low-income families" means families whose income does not exceed 50 percentum of the median family income for the area, as determined by the Secretary with adjustments for smaller and larger families. ${ }^{20}$ Secondly, a "lower-income family" is one who "cannot afford to pay enough to cause private investors in their locality to build an adequate supply of decent, safe, and sanitary buildings for its use."'.21 For one law to use three such fundamentally different poverty definitions to distribute federal funds is unique; moreover, the ability to pay criteria fits very well with the economic definition of poverty we offered above which, essentially, is a budget constraint below a social minimum level.

Title XX of the Social Security Act is yet another example of the administrative use of a poverty line based on median income within a State. Among other things, the Act authorizes federal sharing of the cost of Statesponsored social services other than basic health, education, and institutional services or income maintenance. Under this Act, federal support can be forthcoming for day care programs for children, meals on wheels to shut-ins, family planning, etc. No payment for these services need be made by families whose income is less than the lower of (1) $80 \%$ of the median income for a family of four in the State, or (2) the median income for a family of four in the fifty States and the District of Columbia. If needed, the Secretary makes further adjustments for family size. ${ }^{22} \mathrm{~A}$ fee schedule for the services is established for families whose incomes are between $80 \%$ and $115 \%$ of the median income with the State. 
Listing the various poverty definitions in current use underlines the fact that both official and relative definitions of poverty are in current use to distribute federal funds to States or individuals. We next consider the consequences of one poverty standard as compared to another in terms of which States receive which share of federal funds.

\section{THE IMPLICATION OF POVERTY DEFINITIONS ON THE GEOGRAPHIC DISTRIBUTION OF FEDERAL FUNDS}

In this section, we present several alternative schemes of distributing funds to States. We do not exactly replicate existing distributional schemes, but look for patterns which emerge when using the official poverty standard as compared to a relative poverty standard.

In Table 1 are listed data for the States and census divisions, by population, current poverty standard, the current standard without a farm/non-farm adjustment, a relative poverty standard based on one-half national family income, and a comparable relative poverty standard using median income within a State. Within each of the five columns are two entries, the numeric total for the State or division and the fraction or percent of the total accounted for by the State. The numeric totals are included only for interested readers; our main interest lies with the percentage figures as allocative weights.

A family of allocative schemes is obtained by considering different counts of poor persons under different poverty definitions. In Table 1, in Columns 2 through 5 , are the relative percentages of federal funds that would go to each State under four different poverty definitions. ${ }^{23}$ Whether one uses the current poverty definition, Column 2, or the current definition without a farm adjustment, Column 3, makes little difference in the allocation.

If federal dollars were allocated to States on the basis of the current poverty definition, for instance, the sixteen States and the District of Columbia, an area called the "South," which includes the South Atlantic, East South Central, and West South Central divisions, would receive the largest share, about 45\% of federal poverty dollars. The States in the South, in general, have a greater percentage of poverty than of the population. This means that distribution schemes like Title I of ESEA and parts of CETA, which distribute federal funds to States based on the official poverty thresholds, overcome a "needs difficulty" that is present with a strict per capita distribution scheme.

What happens if we use a relative poverty definition? We shall use a "50 percent of the median income" concept which appears in the 1979 Housing and Community Act. Admittedly, it is rather arbitrary and mainly used here for expository purposes. In this case, the absolute number of poor increases in every State, reflecting in part the higher income thresholds. For example, the official poverty line was $\$ 4,540$ in 1973 for a non-farm family of four persons while the median income for a four-person U.S. family was $\$ 13,710$. However, regardless of whether one uses 50\% of national median income or $50 \%$ of State median income, States that have relatively low average incomes receive relatively 
TABLE 1

Persons in Poverty and Percent of Nation's Poverty by State, Division, and Poverty Definition Using 1970 Census Data (Figures in Hundreds)

\begin{tabular}{|c|c|c|c|c|c|c|c|c|c|c|}
\hline Census Division & \multicolumn{2}{|c|}{$\begin{array}{c}\text { (1) } \\
\text { Population }\end{array}$} & \multicolumn{2}{|c|}{$\begin{array}{l}\text { (2) } \\
\text { \# of Poor } \\
\text { According } \\
\text { to Current } \\
\text { Definition }\end{array}$} & \multicolumn{2}{|c|}{$\begin{array}{c}(3) \\
\text { Current } \\
\text { Definition } \\
\text { Non-farm }\end{array}$} & \multicolumn{2}{|c|}{$\begin{array}{c}(4) \\
\text { One-half } \\
\text { National } \\
\text { Median } \\
\text { Family } \\
\text { Income }\end{array}$} & \multicolumn{2}{|c|}{$\begin{array}{c}(5) \\
\text { One-half } \\
\text { State } \\
\text { Median } \\
\text { Family } \\
\text { Income }\end{array}$} \\
\hline U.S. Total & 1978097 & & 273972 & & 277189 & & 448304 & & 436736 & \\
\hline New England & 9682 & & 728 & & 1136 & & $(18038)$ & & (18034 & \\
\hline Maine & 9570 & $(.48)$ & 1273 & $(.46)$ & 1277 & $(.46)$ & 2497 & $(.56)$ & 1630 & $(.37)$ \\
\hline N.H. & 7145 & $(.36)$ & 713 & $(.26)$ & 720 & $(.26)$ & 1294 & $(.29)$ & 1222 & $(.28)$ \\
\hline $\mathrm{Vt}$ & 4310 & $(.22)$ & 530 & (.19) & 533 & (.19) & 957 & $(.21)$ & 957 & $(.22)$ \\
\hline Mass & 55065 & $(2.78)$ & 4749 & $(1.73)$ & 4750 & $(1.71)$ & 8216 & $(1.83)$ & 8454 & $(1.94)$ \\
\hline RI & 9019 & $(.46)$ & 1124 & $(.41)$ & 1124 & $(.40)$ & 1727 & $(.38)$ & 1727 & $(.40)$ \\
\hline Conn & 29515 & $(1.49)$ & 2037 & $(.74)$ & 2037 & $(.73)$ & 3347 & $(.75)$ & 4044 & (.93) \\
\hline Mid Atlantic & 36640 & & 3244 & & 3149 & & 64704 & & 66180 & \\
\hline$N Y$ & 178238 & (9.01) & 20373 & $(7.44)$ & 20426 & $(7.37)$ & 33279 & $(7.42)$ & 35549 & $(8.14)$ \\
\hline $\mathrm{NJ}$ & 70415 & $(3.56)$ & 5641 & (2.06) & 5654 & (2.04) & 9589 & $(2.14)$ & 11331 & $(2.59)$ \\
\hline $\mathrm{Pa}$ & 115314 & $(5.82)$ & 12536 & $(4.58)$ & 12600 & $(4.54)$ & 21836 & $(4.87)$ & 19300 & $(4.42)$ \\
\hline East North Central & 41893 & & 3923 & $(1.43)$ & 3574 & $(1.29)$ & 66742 & & 72325 & \\
\hline Ohio & 104242 & $(5.27)$ & 10657 & (3.89) & 10795 & $(3.89)$ & 18221 & $(4.06)$ & 18790 & $(4.30)$ \\
\hline Ind & 50611 & $(2.56)$ & 4802 & $(1.75)$ & 4971 & $(1.79)$ & 8844 & $(1.97)$ & 8897 & (2.04) \\
\hline III & 108352 & $(5.48)$ & 11241 & $(4.10)$ & 11333 & $(4.09)$ & 18463 & $(4.12)$ & 21180 & $(4.84)$ \\
\hline Mich & 86954 & $(4.40)$ & 8187 & $(2.99)$ & 8255 & $(2.98)$ & 13496 & $(3.01)$ & 15537 & (3.56) \\
\hline Wisc & 42916 & $(2.17)$ & 4220 & $(1.54)$ & 4402 & $(1.59)$ & 7718 & $(1.72)$ & 7921 & $(1.81)$ \\
\hline West North Central & 12769 & & 1486 & & 1790 & & 37292 & & 38631 & \\
\hline Minn & 37111 & $(1.88)$ & 3979 & $(1.45)$ & 4182 & $(1.51)$ & 7358 & 4) & 7846 & $(1.80)$ \\
\hline Iowa & 27468 & (1.39) & 3119 & $(1.14)$ & 3260 & $(1.18)$ & 5972 & $(1.33)$ & 8899 & $(2.04)$ \\
\hline Mo & 45580 & $(2.30)$ & 6119 & $(2.52)$ & 7061 & $(2.54)$ & 11408 & $(2.54)$ & 10895 & (2.49) \\
\hline N. Dak & 5935 & $(.30)$ & 936 & $(.34)$ & 979 & $(.35)$ & 1746 & $(.39)$ & 1392 & $(.32)$ \\
\hline S. Dak & 6429 & (.33) & 1142 & (.42) & 1215 & (.44) & 2131 & (.47) & 1612 & $(.37)$ \\
\hline Nebr & 14412 & $(.73)$ & 1991 & $(.73)$ & 2076 & $(.75)$ & 3559 & (.79) & 3295 & $(.75)$ \\
\hline Kans & 21610 & (1.09) & 2978 & $(1.09)$ & 3056 & (1.10) & 5118 & $(1.14)$ & 4692 & $(1.07)$ \\
\hline South Atlantic & 30904 & & 4640 & & 4611 & & 84063 & & 76828 & \\
\hline Del & 5341 & $(.27)$ & 617 & $(.23)$ & 621 & $(.22)$ & 1074 & $(.24)$ & 1094 & $(.25)$ \\
\hline $\mathrm{Md}$ & 38128 & $(1.93)$ & 3823 & $(1.40)$ & 3839 & $(1.38)$ & 6349 & $(1.42)$ & 7233 & (1.66) \\
\hline DC & 7197 & $(.36)$ & 1277 & $(.47)$ & 1277 & $(.46)$ & 1908 & $(.42)$ & 2034 & $(.47)$ \\
\hline $\mathrm{Va}$ & 44522 & $(2.25)$ & 6878 & $(2.51)$ & 6969 & $(2.51)$ & 11525 & $(2.57)$ & 10849 & $(2.48)$ \\
\hline W. Va & 17088 & $(.86)$ & 3963 & (1.45) & 3981 & (1.44) & 6112 & $(1.36)$ & 4641 & $(1.06)$ \\
\hline $\mathrm{NC}$ & 48908 & $(2.47)$ & 9753 & (3.56) & 9939 & (3.59) & 15682 & $(3.50)$ & 13401 & (3.07) \\
\hline SC & 24809 & $(1.25)$ & 6136 & $(2.24)$ & 6227 & $(2.25)$ & 9140 & (2.04) & 7890 & (1.81) \\
\hline $\mathrm{Ga}$ & 44645 & (2.26) & 9430 & (3.44) & 9510 & $(3.43)$ & 14394 & $(3.21)$ & 13554 & $(3.10)$ \\
\hline Fla & 66253 & (3.35) & 11131 & (4.06) & 11142 & $(4.02)$ & 17879 & $(3.99)$ & 16132 & (3.69) \\
\hline
\end{tabular}


TABLE 1 (continued)

\begin{tabular}{|c|c|c|c|c|c|c|c|c|c|c|}
\hline Census Division & \multicolumn{2}{|c|}{$\begin{array}{c}\text { (1) } \\
\text { Population }\end{array}$} & \multicolumn{2}{|c|}{$\begin{array}{l}\text { (2) } \\
\text { \# of Poor } \\
\text { According } \\
\text { to Current } \\
\text { Definition }\end{array}$} & \multicolumn{2}{|c|}{$\begin{array}{c}\text { (3) } \\
\text { Current } \\
\text { Definition } \\
\text { Non-farm }\end{array}$} & \multicolumn{2}{|c|}{$\begin{array}{c}(5) \\
\text { One-half } \\
\text { State } \\
\text { Median } \\
\text { Family } \\
\text { Income }\end{array}$} & \multicolumn{2}{|c|}{$\begin{array}{c}(4) \\
\text { One-half } \\
\text { National } \\
\text { Median } \\
\text { Family } \\
\text { Income }\end{array}$} \\
\hline East South Central & 12778 & & 3019 & & 2601 & & 47942 & & 40054 & \\
\hline Ky & 31339 & $(1.58)$ & 7268 & $(2.65)$ & 7473 & $(2.70)$ & 11211 & $(2.50)$ & 9520 & $(2.18)$ \\
\hline Tenn & 38329 & (1.94) & 8367 & $(3.05)$ & 8521 & (3.07) & 13011 & $(2.90)$ & 10607 & $(2.43)$ \\
\hline Ala & 33761 & $(1.71)$ & 8670 & $(3.16)$ & 8761 & (3.16) & 12944 & $(2.89)$ & 11248 & $(2.58)$ \\
\hline Miss & 21659 & $(1.09)$ & 7643 & $(2.79)$ & 7760 & $(2.80)$ & 10776 & $(2.40)$ & 8679 & $(1.99)$ \\
\hline West South Central & 18196 & & 3497 & & 3997 & & 62085 & & 55965 & \\
\hline Ark & 18816 & $(.95)$ & 5173 & $(1.89)$ & 5258 & (1.90) & 7908 & $(1.76)$ & 6075 & (1.39) \\
\hline $\mathrm{La}$ & 35465 & $(1.79)$ & 9608 & $(3.51)$ & 9674 & $(3.49)$ & 13986 & $(3.12)$ & 12063 & $(2.76)$ \\
\hline Okla & 24686 & $(1.25)$ & 4570 & (1.66) & 4671 & (1.69) & 7491 & $(1.67)$ & 6612 & $(1.51)$ \\
\hline Tex & 108854 & $(5.50)$ & 20339 & $(7.42)$ & 20501 & $(7.40)$ & 32700 & $(7.29)$ & 31215 & (7.15) \\
\hline Mountain & 6611 & & 934 & & 1101 & & 19527 & & 18169 & \\
\hline Mont & 6747 & $(.34)$ & 920 & (.34) & 931 & (.34) & 1703 & $(.38)$ & 1626 & $(.37)$ \\
\hline Idaho & 6961 & $(.35)$ & 876 & $(.32)$ & 905 & $(.33)$ & 1649 & $(.37)$ & 1273 & $(.29)$ \\
\hline Wyo & 3227 & $(.16)$ & 390 & $(.14)$ & 397 & $(.14)$ & 727 & $(.16)$ & 707 & $(.16)$ \\
\hline Colo & 21351 & $(1.08)$ & 2688 & $(.98)$ & 2127 & $(.77)$ & 4638 & $(1.03)$ & 4633 & $(1.06)$ \\
\hline N. Mex & 9932 & $(.50)$ & 2323 & $(.85)$ & 2333 & $(.84)$ & 3626 & $(.81)$ & 3234 & $(.74)$ \\
\hline Ariz & 17281 & $(.87)$ & 2657 & $(.97)$ & 2658 & $(.96)$ & 4275 & $(.95)$ & 3990 & $(.91)$ \\
\hline Utah & 10379 & $(.52)$ & 1207 & (.44) & 1215 & (.44) & 2149 & $(.48)$ & 1846 & $(.42)$ \\
\hline $\mathrm{Nev}$ & 4798 & $(.24)$ & 414 & $(.15)$ & 414 & $(.15)$ & 760 & $(.17)$ & 860 & $(.20)$ \\
\hline Pacific & 32998 & & 3590 & & 2996 & & 60298 & & 54543 & \\
\hline Wash & 32990 & (1.67) & 3302 & $(1.21)$ & 3342 & $(1.21)$ & 5579 & $(1.24)$ & 6033 & $(1.38)$ \\
\hline Oreg & 20398 & $(1.03)$ & 2460 & $(.90)$ & 2490 & $(.90)$ & 4108 & $(.92)$ & 4154 & $(.95)$ \\
\hline Calif & 193894 & (10.00) & 21812 & $(7.96)$ & 21869 & $(7.90)$ & 36369 & $(8.11)$ & 42142 & (9.65) \\
\hline Alaska & 2784 & $(.14)$ & 320 & $(.12)$ & 320 & $(.12)$ & 12944 & $(2.88)$ & 685 & $(.16)$ \\
\hline Hawaii & 7344 & $(.37)$ & 758 & $(.28)$ & 758 & $(.27)$ & 1298 & $(.29)$ & 1529 & $(.36)$ \\
\hline
\end{tabular}

Source: U.S. Department of Commerce, Social and Economic Statistics Administration, Bureau of the Census, Detailed Characteristics, U.S. Summary (PC(1)-D1), February 1973.

less federal dollars with a median income poverty standard than with a distributional scheme based on the official poverty scores. The South under a national median standard would receive about $43 \%$ of total federal poverty funds, which is lower than the $45 \%$ it would receive under the current poverty definition. If a State median income standard was used, even fewer federal dollars, roughly $39 \%$, would go to the South.

Use of a single National income poverty standard can be generally stated as treating individuals or families in the nation equally who are equal in some reference category such as family income. In contrast, the State median income poverty standard says that a family with a 1969 annual income of 
$\$ 5,790$ was poor if they lived in New Jersey, but not poor if they lived ten miles away in New York. New Jersey will receive relatively more poverty dollars with a State family income poverty standard than New York, because relatively more very rich persons live in New Jersey than New York.

The point is that income equalization can be approached locally, as for persons within a State, or nationally. In seeking to relieve the lot of poor persons, this income equalization issue arises. In the local case, if one allocates federal funds on a relative-poverty basis, using State income averages, the pre-transfer existence of more rich persons in the State serves to attract more federal funds. This, in effect, is very similar to what is done under parts of several existing federal allocative schemes, such as The Housing and Community Development Act of 1979 and Title XX of the Social Security Act which use State-income relative poverty distribution schemes. In contrast, under distribution schemes based on a single national standard, relatively low-income states like Mississippi gain. Examples of such schemes using a single national standard are CETA's $\$ 7,000$ income limit or the official poverty standard in Title I of the Elementary and Secondary Education Act.

\section{Alternative Distribution}

A key part of federal fund distribution schemes to the States for poor persons is the derivation of allocative weights and the derivation and use of equivalency scales. In an earlier section we noted that region-specific price indexes, using either an average basket of basic goods, or just food, could be developed and used to adjust and update poverty thresholds, but such adjustments are not made. The predominant current practice is to set a single poverty threshold for the nation and to use such a standard for several different programs. Two important exceptions were noted, however. First, the 1979 Housing and Development Act includes, in its "low-income family" definition, the concept of a Marshallian supply price: a family is poor if it cannot pay a local builder his price for a safe, decent, sanitary building. While loaded with potential administrative problems, this definition has much to commend it. Local standards are set to local needs and constraints, and thus, the rule addresses regional price and income differentials. Also, poverty in housing is tied to the local price of housing and thus the rule satisfies relatively well a type of target efficiency: transfers are linked to the main deprivation criteria. A second exception to the use of a single national threshold involves the use of State income averages in relative poverty distribution schemes. A problem here is that pre-transfer income differentials between States are exacerbated by such schemes.

The Housing Act supply-price allocative rule, cited above, is conceptually attractive, but probably difficult to administer because it requires regular survey data for both house-builders and potential buyers. The relative poverty State income average scheme is also sensitive to subnational differences, but gives more funds to richer States and less to poorer States and thus to many 
persons it may be considered unfair. Fortunately, there is an expedient alternative: use of the inverse of the State income averages as distributional weights. To pay more funds to a relatively poor State and less to a relatively rich State is preferred on vertical equity grounds. We next consider the impact of such a scheme on the allocation of federal funds to poor school children, a target group in Title I of ESEA.

In Table 2 are shown several alternative federal fund allocative schemes under several poverty definitions. Poor school-aged children counts form the base on which the allocative weights are built. In Columns 1, 2, and 3 are shown, respectively, poverty counts of school children using three poverty definitions: the current official measure, National Median Income, and State Median Income relative measures. Again, as noted earlier for the overall population, relatively rich States stand to receive more funds than poorer States if one uses a median poverty definition than with the current poverty definition. To correct this situation, if we assume that the income distribution shapes are similar from one State to another and that only the median incomes differ, then one way to approach distributional parity is to weight the number of poor students by the reciprocal of the median income of the State. In this manner, one can avert the perverse distributional consequences noted above which result from the use of a median income poverty definition, especially State median income.

Columns 5, 6, and 7 of Table 2 present relative allocative weights associated with Census-Orshansky, National Median Income, and State Median Income poverty standards, respectively. The effect of the inverse of State median income is to allocate less federal funds to States that are already relatively welloff. Relatively low income States, obviously, would experience the reverse.

Also, note the numbers in Columns 1,2, and 3 of Table 2 which can be used to distribute funds. That is, New York with 56,300 out of 803,000 children who are poor with the current poverty score, Column 1, would receive $7 \%$ of federal funds whereas Mississippi would receive only $3.3 \%$. In contrast in Column 5 we note that New York would receive only $5.6 \%$ and Mississippi $4.8 \%$ in the income-weighted distribution scheme.

Several criticisms can be made of the proposed alternative distribution scheme. First, the data base reflects 1969 conditions which may not be relevant today. This points to a need for State-specific income data to be collected more frequently. Secondly, the goal of Title I is to provide aid to educationally disadvantaged children. We have not provided school-district poor counts. A third criticism also points to the need for more data. Implied in the State income-weighting procedure is the assumption that price levels do not vary among States and hence that nominal income levels reflect real income levels. If, in high income States, relative prices of goods and services are higher, and if, in high income States, there exist greater gaps between the input requirements for a given educational standard and the local fiscal capacity, then use of the income inverse weight may have been too severe on high-income States. 
TABLE 2

Poor Related School Children: Weighted Distributional Schemes Using Alternative Poverty Counts and State Median Family Income for 1970

\begin{tabular}{|c|c|c|c|c|c|c|c|}
\hline & $\begin{array}{c}1 \\
\text { Poverty Numbers } \\
\text { based on current } \\
\text { Census SSA Poverty } \\
\text { Thresholds } \\
\text { (Non-Farm) }\end{array}$ & $\begin{array}{c}2 \\
\text { Poverty Numbers } \\
\text { based on one-half } \\
\text { National Median } \\
\text { Family Income } \\
\text { Using SSA, Non- } \\
\text { Farm Equivalency } \\
\text { Scales }\end{array}$ & $\begin{array}{c}3 \\
\text { Poverty Numbers } \\
\text { based on one-half } \\
\text { State Median Family } \\
\text { Income Using SSA, } \\
\text { Non-Farm } \\
\text { Equivalency Scales }\end{array}$ & $\begin{array}{c}4 \\
1969 \\
\text { Median } \\
\text { Family } \\
\text { Income }\end{array}$ & $\begin{array}{l}5 \\
\text { Allocation Scheme } \\
\text { set by percentage of } \\
\text { Nation for product } \\
\text { of Col } 1 \times 1 / \mathrm{Col} 4\end{array}$ & $\begin{array}{l}6 \\
\text { Allocation Scheme } \\
\text { set by percentage of } \\
\text { Nation for product } \\
\text { of } \mathrm{Col} 2 \times 1 / \mathrm{Col} 4\end{array}$ & $\begin{array}{c}7 \\
\text { Allocation Scheme } \\
\text { set by percentage of } \\
\text { Nation for product } \\
\text { of Col } 3 \times 1 / \mathrm{Col} 4\end{array}$ \\
\hline U.S. Total & 8030.0 & 13349.2 & 13007.3 & 9596 & & & \\
\hline New England & 268.7 & 471.9 & 494.4 & 10731 & 2.84 & 3.12 & 3.24 \\
\hline Maine & 36.4 & 47.5 & 47.5 & 8220 & .48 & .40 & .40 \\
\hline $\mathrm{NH}$ & 15.7 & 33.8 & 31.2 & 9698 & .18 & .24 & .22 \\
\hline Vt. & 14.3 & 28.8 & 24.1 & 8974 & .17 & .22 & .18 \\
\hline Mass. & 121.8 & 226.5 & 233.9 & 10981 & 1.22 & 1.43 & 1.48 \\
\hline R.I. & 28.1 & 42.6 & 43.0 & 9734 & .31 & .30 & .30 \\
\hline Conn. & 52.4 & 92.7 & 114.7 & 12045 & .47 & .53 & .66 \\
\hline Mid Atlantic & 1033.0 & 1835.4 & 1881.9 & 10472 & 10.86 & 12.24 & 12.48 \\
\hline N.Y. & 563.7 & 952.9 & 1024.6 & 10719 & 5.78 & 6.18 & 6.66 \\
\hline N.J. & 151.1 & 277.3 & 334.3 & 11589 & 1.42 & 1.66 & 2.01 \\
\hline $\mathrm{Pa}$. & 318.2 & 605.2 & 523.0 & 9568 & 3.64 & 4.40 & 3.81 \\
\hline East North Central & 1058.0 & 1929.3 & 2155.0 & 10660 & 10.88 & 8.59 & 14.09 \\
\hline Ohio & 288.7 & 525.2 & 547.6 & 10376 & 3.05 & .64 & 3.68 \\
\hline Ind. & 123.3 & 250.6 & 282.5 & 9967 & 1.35 & .61 & 1.97 \\
\hline Ill. & 308.9 & 537.1 & 628.3 & 11096 & 3.05 & 3.36 & 3.94 \\
\hline Mich. & 222.1 & 391.1 & 465.0 & 11174 & 2.17 & 2.43 & 2.90 \\
\hline Wisc. & 115.0 & 225.3 & 231.6 & 10080 & 1.25 & 1.55 & 1.60 \\
\hline West North Central & 559.8 & 1034.4 & 961.5 & 9017 & 6.90 & 8.06 & 7.47 \\
\hline Minn. & 104.4 & 206.7 & 221.4 & 9928 & 1.15 & 1.44 & 1.55 \\
\hline Iowa & 78.0 & 160.6 & 141.7 & 9055 & .94 & 1.23 & 1.09 \\
\hline Mo. & 180.9 & 306.2 & 288.3 & 8935 & 2.22 & 2.38 & 2.25 \\
\hline N. Dak. & 31.7 & 56.6 & 46.1 & 7836 & .44 & .50 & .41 \\
\hline S. Dak. & 34.3 & 67.7 & 47.7 & 7490 & .50 & .62 & .44 \\
\hline
\end{tabular}




\begin{tabular}{|c|c|c|c|c|c|c|c|}
\hline Nebraska & 55.6 & 102.6 & 94.7 & 8597 & .70 & .83 & .76 \\
\hline Kansas & 74.9 & 134.0 & 121.6 & 8725 & .94 & 1.06 & .97 \\
\hline South Atlantic & 1667.5 & 2619.9 & 2407.6 & 8564 & 22.06 & 21.88 & 19.97 \\
\hline Del. & 18.8 & 34.2 & 35.4 & 10255 & .20 & .23 & .24 \\
\hline Md. & 113.3 & 194.1 & 227.0 & 11206 & 1.10 & 1.20 & 1.41 \\
\hline D.C. & 39.3 & 61.8 & 65.8 & 9606 & .44 & .44 & .47 \\
\hline $\mathrm{Va}$ & 219.3 & 354.0 & 345.2 & 9076 & 2.64 & 2.79 & 2.65 \\
\hline W. Va. & 113.6 & 179.2 & 132.9 & 7414 & 1.68 & 1.68 & 1.25 \\
\hline N.C. & 314.4 & 493.0 & 424.0 & 7770 & 4.43 & 4.41 & 3.80 \\
\hline S.C. & 221.0 & 315.2 & 278.3 & 7620 & 3.17 & 2.87 & 2.54 \\
\hline Ga. & 313.2 & 474.2 & 447.4 & 8174 & 4.20 & 4.03 & 3.81 \\
\hline Fla. & 314.6 & 504.2 & 451.6 & 8274 & 4.16 & 4.23 & 3.80 \\
\hline East South Central & 1027.6 & 1521.4 & 1261.0 & 7166 & 16.12 & 15.08 & 12.52 \\
\hline Ky. & 217.1 & 338.6 & 277.2 & 7439 & 3.19 & 3.16 & 2.59 \\
\hline Tenn. & 256.8 & 398.6 & 322.9 & 7446 & 3.78 & 3.72 & 3.02 \\
\hline Ala. & 288.3 & 413.2 & 361.4 & 7263 & 4.35 & 3.95 & 3.47 \\
\hline Miss. & 265.4 & 371.0 & 299.5 & 6068 & 4.79 & 4.25 & 3.44 \\
\hline West South Central & 1270.6 & 1957.8 & 1768.8 & 7964 & 17.83 & 17.36 & 15.61 \\
\hline Ark. & 163.4 & 240.1 & 185.7 & 6271 & 2.85 & 2.66 & 2.06 \\
\hline La. & 330.2 & 476.1 & 410.3 & 7527 & 4.80 & 4.40 & 3.80 \\
\hline Okla. & 122.7 & 199.1 & 174.2 & 7720 & 1.74 & 1.79 & 1.57 \\
\hline Tex. & 654.3 & 1042.5 & 998.6 & 8514 & 8.42 & 8.51 & 8.18 \\
\hline Mountain & 355.7 & 618.6 & 573.5 & 9112 & 4.40 & 4.81 & 4.45 \\
\hline Mont. & 25.9 & 55.9 & 53.0 & 8547 & .33 & .45 & .43 \\
\hline Idaho & 24.2 & 47.2 & 36.4 & 8405 & .32 & .39 & .30 \\
\hline Wyo. & 9.5 & 20.6 & 20.1 & 9030 & .11 & .15 & .15 \\
\hline Colo. & 80.3 & 138.0 & 137.6 & 9568 & .92 & 1.00 & 1.00 \\
\hline N. Mex. & 88.1 & 134.1 & 119.7 & 7845 & 1.23 & 1.18 & 1.06 \\
\hline Ariz. & 85.0 & 137.6 & 129.3 & 9206 & 1.01 & 1.03 & .97 \\
\hline Utah & 31.6 & 63.2 & 52.3 & 9432 & .37 & .47 & .38 \\
\hline Nev. & 11.1 & 22.0 & 25.1 & 10779 & .11 & .14 & .16 \\
\hline Pacific & 789.1 & 1330.0 & 1533.6 & 10691 & 8.07 & 8.62 & 9.95 \\
\hline Wash. & 79.0 & 142.1 & 155.6 & 10489 & .82 & .94 & 1.03 \\
\hline Oreg. & 59.5 & 106.8 & 108.2 & 9498 & .68 & .78 & .79 \\
\hline Calif. & 619.5 & 1022.8 & 1198.3 & 10828 & 6.27 & 6.57 & 7.71 \\
\hline Alaska & 9.1 & 16.6 & 22.6 & 12507 & .08 & .09 & .13 \\
\hline Hawaii & 22.0 & 41.7 & 48.9 & 11664 & .20 & .24 & .29 \\
\hline
\end{tabular}

Source: U.S. Department of Commerce, Social and Economic Statistics Administration, Bureau of the Census, Detailed Characteristics, U.S. Summary (PC(1)-D1), February 1973. 
What is needed are State-specific measures of real gaps between needs and fiscal capacity. ${ }^{24}$

\section{SUMMARY AND CONCLUSION}

Each year the federal government distributes several billion dollars to States using allocative schemes which depend, in part, on different poverty definitions. How one defines poverty can thus make more than an academic difference to a State. This paper has first included a general review of important issues one must consider in developing economic definitions of poverty. How the poverty standard is set and how it is adjusted over time are two important aspects in distinguishing the two main alternative poverty definitions: absolute and relative poverty. Within each concept, geographic transfer adjustments can be made according to several procedures outlined in Section Two. This is not generally done, however. Instead, regional differences in "need" are approximated in several major federal laws, such as Title XX of the Social Security Act, by the use of State-specific income averages. Unfortunately, this results in States with lower average incomes receiving relatively less federal funds and rich States receiving more funds than when the single national norm is used. A single set of 124 thresholds, as used in the official poverty standard with equivalency scale adjustments, could be made sensitive to regional real income disparities by the use of a region-specific CPI to update poverty thresholds. Alternatively, the reciprocals of State-income averages could be used to mitigate the apparent adverse distributional consequences of allocative schemes which use State average income to disburse funds to States. Ideally, antipoverty federal fund transfers to States should involve formulae based on regular calculations of local fiscal capacity and fiscal needs. ${ }^{25}$ Until these are available, the methods offered here may be useful. In addition, future research on this topic should consider the allocative implications of both (1) alternatives to the census income measures and (2) the alternative poverty measures.

\section{FOOTNOTES}

1. "The post-tax/post-transfer poverty counts do not improve the status of the South compared to the other regions. In fact, the differential is widened. Before taxes and transfers, the incidence of poverty is roughly 30 percent higher in the South than in the North Central region. After taxes and transfers, although there is an absolute reduction in poverty in both regions, the incidence of poverty in the South $(12.1$ percent) increases to more than twice that of the North Central region (5.9 percent).' Source: Congress of the United States, Congressional Budget Office Working Paper No. 17, Poverty Status of Families Under Alternative Definitions of Income, (Wash. D.C., USGPO), June 1977, p. 14.

For a conceptual discussion of measuring income and poverty see Stanley P. Stephenson,
Jr., "Relative Measure of Poverty," Technical Appendix XIV, The Measure of Poverty, U.S. Department of Health, Education, and Welfare, 1976.

2. Mollie Orshansky, "Children of the Poor," Social Security Bulletin, July 1963 and "Counting the Poor: Another Look at the Poverty Profile," Social Security Bulletin, January 1965.

3. Basically the standard involves pricing a variety of normative family food plans, developed, in part, by the Department of Agriculture. These food plans, reflecting individual nutritional adequacy intake levels, "economies of scale" for increasing family size, adjustments for age and sex of family head, and farm vs. non-farm residence, are multiplied by three on the assumption that 
food will equal one-third of the total budget. These adjustments result in 124 different poverty thresholds depending on family size, type, and location. By comparing family income data from the March Current Population Survey to the calculated poverty thresholds, families are considered poor or not and official poverty counts are obtained. (This well-known ratio, derives from Engel's Law and survey data in one week of 1955: the ratio of food expenditures to after-tax income of families with at least two persons was onethird.)

4. A Note on Equivalency Scales. An important element in the official poverty thresholds is the relationship between the various 124 poverty thresholds. For example, in 1973, a male-headed, non-farm family of four persons with two children had a poverty threshold of $\$ 4,505$ whereas a second four-persen family with one child, but otherwise identical, had a poverty threshold of $\$ 4,666$. Presumably, consumption needs of the two families are such that incomes of the two families are equivalent. In this paper a four-person, nonfarm family with two children and a male household head is regarded as the base family with a scale factor of 100 . Replacing one child with an adult increases the scale factor to 104 which implies that a poverty threshold for the second family is about four percent above that for the base family. The main factor contributing to equivalency scale adjustments is family size which mainly reflects the cost of food for families of different sizes (and composition). However, the official poverty thresholds also reflect adjustments for farmnon-farm location, sex of household head, and family composition. In order to insure comparability in comparisons between poverty thresholds, we use the same equivalency scales used in the Orshansky thresholds to adjust the incomes under the relative poverty concept. That is, we consider the median one-half the income of four-person non-farm family as the base family income with a scale of 100 and adjust the relative poverty thresholds for different families exactly corresponding to the adjustments made in the Orshansky equivalency scales.

5. Lester C. Thurow, Poverty and Discrimination (Washington, D.C.: The Brookings Institution, 1979), p. 21.

6. Harold W. Watts, "An Economic Definition of Poverty," Chapter 11 in On Understanding Poverty, Daniel P. Moynihan, ed., New York, Basic Books, Inc. 1969.

7. Theodore W. Schultz, "Investing in Poor People: An Economist's View," American Economic Review, Papers and Proceedings, May 1965, pp. 511-512.

8. Harry G. Johnson, "Approaches to the Reduction of Poverty: II," comment on paper by Professor Lampman at the 1964 American
Economic Association meetings, reviewed in Edward C. Budd, ed., Inequality and Poverty (New York: W. W. Norton, 1967), p. 183.

9. Burton A. Weisbrod, The Economics of Poverty (Englewood Cliffs, New Jersey: PrenticeHall), p. 13.

10. Martin Rein, "Problems in the Definition and Measurement of Poverty" in Poverty in America, ed. Louis A. Ferman et al. (Ann Arbor: University of Michigan Press, 1968), 116-133. Also see further discussion on externality attributes of poverty in Eugene Smolensky, "Investment in the Education of the Poor: A Pessimistic Report," American Economic Review, May 1966.

11. Victor Fuchs, "Toward a Theory of Poverty" in The Concept of Poverty (Washington, D.C.: U.S. Chamber of Commerce, 1965), pp. 71-91. Also see his "Redefining Poverty and Redistributing Income," The Public Interest, No. 8, Summer 1967, pp. 88-95.

12. Proponents of this poverty standard point out that by relating poverty to real income changes, income thresholds are kept current and in step with changes in national productivity. Secondly, use of the median income pinpoints national concern with income distribution, which is consistent with the premise, held by proponents of this standard, that poverty really involves income inequality. More specifically, Lorenz-type measures of poverty focus on the entire income distribution, whereas the Fuchs-type poverty line depends only on the shape of the distribution among the lower half of the population. In addition, the Fuchs measure is concerned with the income gap between those who have the least income and those who have the average income. (Also see, Mary Jean Bowman, "Poverty in an Affluent Society" in Neil Chamberlin, ed., Contemporary Economic Issues (Homewood, Illinois: Richard Irwin, Inc., 1969), p. 54.)

13. John Riew correctly observed that the issue may also involve interregional efficiency issues as well as equity issues. That is, greater efficiency might be served by allowing persons to move from a high-priced region to a lowpriced region-rather than setting higher grant levels for persons in former area based on higher average price levels and, presumptively, greater needs

Also, we do not consider the alternative used in Florida which involves a separate market basket for each county. On a national scale such a scheme would be too costly. For a discussion of the Florida case, see Gary Cooper, "Spatial Price Indices: The Florida Experience," Review of Regional Studies, Fall, 1976, Vol. 6, No. 2, pp. 36-47.

14. John S. Akin and Stanley P. Stephenson, Jr., "The Regional Impact of Recent Inflation by Income Class," Review of Regional Studies, Spring 1976, Vol. 6, No. 1, pp. 28-34. 
15. Harold W. Watts, "The Iso-Prop Index: An Approach to the Determination of Differential Poverty Income Thresholds," The Journal of Human Resources, Vol. II, No. 1, Winter, 1967.

16. Don Bellante and Ruth Ann Killion, "The Adjustment of Spatial Price Indexes for Geographical Differences in Standards of Consumption: An Application of the Hedonic Method," Review of Regional Studies, Spring 1976, No. 1, pp. 109-113.

17. Jack McNeil, "Relative Poverty," Technical Paper No. XII in The Measure of Poverty, 1977, USGPO/HEW.

18. United States Code Annodated (USCA) $\S 802$, pp. 110-113, 1980

19. (29 USCA, §842a (1)(iii) 1980).

20. (42 USCA, $\$ 1437$ a, p. 26, 1980).

21. Ibid. p. $25 \& 26$.

22. (42 USCA, $\$ 1397$ a p. 344,1980 ).

23. A per capita distribution scheme such as indicated in Table 1, Column 1, is a convenient reference scheme. It implies uniform needs between individuals. In particular, it con- siders the need of a poor person to be identical to someone who is not poor. Many would object because densely populated areas such as Northeast, who have relatively few poor, would receive more than their "fair share" of federal dollars. States like New York, New Jersey, and Michigan have relatively more people than poor people. On the other hand, the percent of the nation's official poor in a Southern State like Mississippi, 2.8 percent, far exceeds the percent of the nation's population in that State, 1.09 percent. The point is that if one follows a criteria that federal funds designated to poor persons should be allocated according to the location of those poor persons, then an alternative distribution scheme to population counts is needed.

24. As an intermediate step in this process, Statespecific average prices for goods and services could also be used to adjust official poverty lines.

25. For example, federal revenue sharing to the State is now based on State-specific measures of fiscal capacity and tax efforts. 